\title{
DIALEKTIKA AGAMA DAN NEGARA \\ DALAM KARYA JURGEN HABERMAS
}

\author{
Oleh: \\ Sun Choirol Ummah \\ SunChoirolUmmah@uny.ac.id
}

\begin{abstract}
Abstrak
Agama di negara sekuler dianggap tidak memiliki pengaruh sama sekali terhadap dinamika negara. Habermas melalui teori rasio komunikatif, etika diskursus, dan demokrasi deliberatif pada akhirnya memandang bahwa dalam negara demokratis yang terdapat dialog antara agama dan negara justru menunjukkan betapa agama mampu menggerakkan negara untuk selalu beradaptasi dan saling berkomunikasi. Cara yang digunakan yakni agama harus mentransformasi diri dari agama mitis (religious-metaphysical) ke agama rasional (religiouspost-metafisik). Di sini warga beragama dan warga sekuler dalam masyarakat post-sekuler dapat saling belajar satu sama lain. Warganegara beriman juga mesti belajar dari sains dan teknologi yang memiliki klaim-klaim kesahihan ilmu pengetahuan. Warganegara beriman juga harus tunduk dan mengakui rasio sekuler yang menjadi basis legitimasi negara hukum demokratis.
\end{abstract}

Kata kunci: agama, komunikasi, negara

\section{PENDAHULUAN}

Modernitas yang melanda dunia, dalam banyak hal juga memengaruhi agama. Pada sekitar tahun 1989-1990, terorisme dari berbagai kelompok agama fundamentalis bermunculan, tidak hanya melanda Timur Tengah tetapi juga di Afrika, Asia Tenggara, dan di kawasan anak benua India. Mereka merasa terhina disebabkan oleh peradaban Barat yang lebih unggul. Tidak hanya itu, mereka juga terjebak dalam konflik nasional ataupun antar etnis. Ada juga gejala lain misalnya di Iran yang memrotes rezim pemerintahan yang didukung Barat. Di berbagai negara Islam dan Israel, hukum agama digunakan sebagai alternatif menggantikan hukum sekuler. Di Afganistan, menyusul di Irak, konstitusi liberal dibatasi dan disesuaikan dengan hukum syariah. Demikian pula hubungan internasional Timur dan Barat berubah menjadi sangat menakutkan.

Habermas mengakui bahwa dirinya bukanlah seorang yang berbakat dalam hal agama (religiös unmusikalisch). Meski demikian, bukan berarti Habermas tidak berpikir tentang permasalahan agama. Sebaliknya, ia secara serius memikirkan peran agama dalam negara hukum demokratis. Keseriusannya itu bukan tanpa 
alasan. Setelah sekian lama agama didomestifikasi menjadi urusan prifat dan dilenyapkan dari ruang publik oleh abad Pencerahan (Aufklärung) yang mengusung rasio sekuler, ternyata agama tidak hilang sama sekali. Alih-alih mematikan agama dengan mendomestifikasikannya, yang terjadi malah sebaliknya, agama seolaholah mendapat energi baru selama didomestifikasi dan sekarang merangsek ke ruang publik.

Melihat kenyataan yang demikian, Habermas dalam Religion in the Public Sphere mencoba mengulas permasalahan posisi agama dalam negara hukum demokratis, seperti pembahasan dalam tulisan ini.

\section{RIWAYAT HIDUP HABERMAS}

Jürgen Habermas adalah seorang filsuf dan sosiolog Barat abad ke-20 yang lahir di Dusseldorf pada 18 Juni 1929, dan dibesarkan di Gummersbach, Jerman dalam lingkungan Protestan. Ayahnya, Ernst Habermas adalah seorang Kepala Jawatan Perdagangan dan Industri, sedang kakeknya seorang pendeta dan direktur seminari lokal (Ibrahim Ali Fauzi, 2003: 18). Habermas dikenal sebagai generasi kedua dari Mazhab Frankfurt yang beraliran filsafat Kontinental. Lain dari itu, ia juga penerus dari Teori Kritis yang ditawarkan oleh para pendahulunya (Max
Horkheimer, Theodor W. Adorno, dan Herbert Marcuse). Namun Teori Kritis yang dipaparkan oleh para pendahulunya berakhir dengan kepesimisan atau kebuntuan. Selanjutnya Habermas mencoba membangkitkan kembali teori itu dengan paradigma baru.

Saat Habermas memasuki usia remaja diakhir Perang Dunia II, ia baru menyadari akan kejahatan rezim nasional-sosialis dibawah kepemimpinan Adolf Hitler. Hal ini yang mendorong pemikiran Habermas terhadap pentingnya demokrasi di negaranya dan pengalaman ini pula yang selalu dijadikan titik sentral untuk karyakaryanya.

Pada tahun 1949, Habermas memulai studi di Universitas Gottingen Jerman. Di samping mempelajari kesusasteraan, sejarah, dan filsafat aliran Nicolai Hartmann, Habermas mengikuti kuliah psikologi dan ekonomi (Bertens, 2002: 236). Setelah itu, ia meneruskan studi filsafat di Zürich pada tahun 1950-1951 dan dilanjutkan di Universitas Bonn (1951-1954) yang pada tahun 1954 meraih gelar "doktor filsafat" dengan sebuah disertasi berjudul Das Absolute und die Geschichte. Von der Zweispältigkeit in Schellings Denken (yang Absolut dan Sejarah, studi tentang pemikiran Schelling). 
Pada saat tahun 1950-an Habermas mulai menekuni karya Theodor Adorno dan Max Horkheimer. Ia juga mempelajari pikiran-pikiran Marx dan Hegel muda pada Karl Löwith, seorang sarjana dan guru besar Jerman (Ibrahim Ali Fauzi, 2003: 20). Berbarengan dengan itu juga, ia mulai lebih aktif dalam diskusi-diskusi politik. Hal ini juga yang mendorong Habermas untuk masuk ke partai National Socialist Germany (Listiyono, 2007: 220).

Pada tahun 1956 Habermas bergabung dengan Mazhab Frankfurt atau yang dikenal dengan Institut Penelitian Sosial (Institut fur Sozialforschung). Ia memutuskan hal ini karena percaya bahwa Adorno dan Horkheimer merumuskan sebuah teori dialektis dan teori kritis masyarakat dari tradisi yang kreatif dan inovatif. Habermas kemudian menjadi asisten dari Adorno dan ia juga banyak belajar tentang sosiologi dari Adorno. Setelah Habermas bekerja di institut tersebut, ia makin berkenalan dan bersentuhan dengan pemikiran Marxisme.

Sekitar waktu yang sama Habermas menyiapkan Habilitationsschift-nya, semacam karya yang harus ditulis seorang sarjana sebelum diberi izin menjadi dosen di sebuah universitas. Karangan ini selanjutnya diberi judul Strukturwandel der Öffentlichkeit; Untersuchungen zu einer Kategorie der Bürgerlichen
Gesellschaft (Perubahan dalam Struktur Pendapat Umum, 1962), suatu studi yang mencermati kemungkinan demokrasi masih berlaku dalam masyarakat modern. Fokus utama dari tulisan itu adalah tentang berfungsi tidaknya pendapat umum dalam masyarakat modern. Pada kurun waktu yang sama, Habermas diundang menjadi profesor filsafat Universitas Hiedelberg (1961-1964). Pada tahun 1964, ia kembali ke Universitas Frankfurt, karena diangkat menjadi profesor sosiologi dan filsafat mengantikan Horkheimer (1964-1971). Pada 1964 ia juga sempat menjadi profesor filsafat di Universitas J. Von Goethe Frankfurt.

Pemikiran Marx yang sudah dikenal Habermas sejak di Mazhab Frankfurt cukup memengaruhi pemikirannya secara utuh. Perannya sebagai seorang Marxis tampak ketika ia turut berperan serta dalam gerakan mahasiswa Frankfurt. Sekitar tahun 1960-1970-an merupakan periode demonstrasi gerakan mahasiswa kiri baru yang dinilai radikal sedang marak. Sebagai seorang pemikir Marxis, ia cukup dikenal oleh gerakan mahasiswa tersebut, bahkan sempat menjadi ideolognya, walaupun keterlibatannya hanya mengerjakan segi teoritisnya. Habermas sangat populer dikalangan kelompok yang bernama Sozialistischer Deutsche Studentenbund (Kelompok Mahasiswa Sosialis Jerman) 
(Ibrahim Ali Fauzi, 2003: 20-21). Selanjutnya, bersama sebuah tim von Freidburg, Oehler, Weltz, ia mengambil bagian dalam suatu proyek penelitian mengenai sikap politik mahasiswa di Universitas Frankfurt. Hasil penelitiannya dipublikasikan dalam sebuah buku Student und Politik (Mahasiswa dan Politik, 1964).

Akan tetapi, kedekatan Habermas dengan kelompok mahasiswa yang beraliran kiri (radikal) tidak terlalu lama. Hal itu dikarenakan, aksi-aksi mahasiswa yang mulai melewati ambang batas, menggunakan tindak anarkis atau tindak kekerasan. Akibatnya, Habermas mengkritik tindakan mahasiswa yang melampaui batas tersebut. Akan tetapi, akibat dari kritikan tersebut, Habermas harus bernasib sama dengan Horkheimer dan Adorno, yang terlibat konflik dengan mahasiswa.

Di dalam bukunya yang diterbitkan pada tahun 1969 yang berjudul Protestbewegung ung Hochschulreform (Gerakan Oposisi dan Pembaruan Perguruan Tinggi) Habermas mengkritik secara pedas aksi-aksi kekerasan yang dilakukan oleh mahasiswa kiri. Bagi Habermas, aksi-aksi yang dilakukan oleh para mahasiswa kiri tersebut dikecam sebagai 'revolusi palsu', bentuk-bentuk pemerasan yang diulang kembali, dan kontraproduktif.
Akhirnya, Habermas dengan mahasiswa beraliran kiri tersebut makin bertentangan. Hal ini mendorong Habermas untuk keluar dari Universitas Frankfurt. Habermas menerima tawaran untuk bekerja di Max Planck Institut di kota Stanberg sebagai peneliti. Habermas bekerja di sana selama 10 tahun sampai lembaga penelitian ini dibubarkan. Selama di Max Planck Institut, Habermas telah mencapai kematangan pemikiran filosofisnya. Thomas McCarty, penerjemah spesialis karya-karya Habermas dari bahasa Jerman ke bahasa Inggris mengomentari bahwa Habermas adalah tokoh terkemuka dalam iklim intelektual di Jerman dewasa ini, sebagaimana yang telah ia alami sejak dekade lalu. Hampir tak ada bidang kemanusiaan atau ilmuilmu sosial yang tidak merasakan pengaruh pemikirannya. Ia adalah raja, dalam keluasan maupun kedalaman, dari sederet literatur yang lebih dispesialisasikan. Bahkan kontribusinya pada filsafat dan psikologi, ilmu politik dan sosiologi, sejarah ide-ide dan teori sosial dibedakan bukan hanya dengan keleluasaan atas bidang-bidang itu, tapi dengan kesatuan perspektif yang termuat di dalamnya. Kesatuan ini berasal dari sebuah misi kemanusiaan (Ibrahim Ali Fauzi, 2003: 1718). 
Banyak karya tulis yang dibuat Habermas selama di Max Planck Institut, antara lain: Legitimations Probleme im Spatkapitalismus (Masalah Legitimasi dan Kapitalisme Lanjut, 1973), Kultur und Kritik (Kebudayaan dan Kritik, 1973); Zur Rekonstruktion des Historischen Materialismus (Rekonstruksi Materialisme Historis, 1976). Selain itu, masih ada satu karya tulis Habermas yang dapat dikatakan sebagai magnum opusnya dan puncak seluruh usaha ilmiahnya adalah Theorie des kommunikativen Handelns (Teori tentang Praksis Komunikatif, dua jilid, 1981). Hingga tahun 1988 tidak kurang dari 27 karyanya baik berupa buku, jurnal, maupun pidato-pidatonya dipublikasikan, belum lagi berbagai tulisannya yang tersebar di 12 jurnal lainnya (Ibrahim Ali Fauzi, 2003: 20-26).

Pada akhirnya, Habermas kembali ke Universitas Frankfurt sebagai profesor filsafat. Ia mengajar di Universitas Frankfurt sampai memasuki masa pensiunnya pada tahun 1994. Pada waktu itu, Habermas sudah memiliki reputasi internasional yang besar dan banyak diminta untuk berbicara di berbagai pertemuan atau diskusi ilmiah.

\section{PIJAKAN PEMIKIRAN HABERMAS}

Bagaimana sesungguhnya

Habermas berpikir tentang agama, terutama posisi agama di dalam negara hukum demokratis? Dalam pemikirannya tentang posisi agama dalam negara hukum demokratis, Habermas menempatkannya dalam bingkai teorinya tentang rasio komunikatif, etika diskursus (discourse ethics), dan demokrasi deliberatif.

\section{Rasio Komunikatif}

Sebelum memaparkan pemikiran tentang rasio komunikatif, Habermas terlebih dahulu menggambarkan secara singkat kemunculan ilmu pengetahuan modern yang menekankan kesanggupan rasio manusia untuk memeroleh pengetahuan (Francisco Budi Hardiman, 1990: 22-26), berlanjut pada positifikasi rasio sehingga menjadi rasio intrumental dalam positivisme logis.

Abad Pencerahan (Aufklärung) menjadi titik awal bagi perkembangan ilmu pengetahuan modern. Dalam ilmu pengetahuan modern, rasio manusia menjadi acuan utama untuk pemerolehan pengetahuan. Dalam filsafat modern itu sendiri terdapat dua blok besar yakni rasionalisme dan empirisisme. Rasionalisme menekankan bahwa pengetahuan murni dapat diperoleh melalui kemampuan rasio manusia itu sendiri. Oleh karenanya pengetahuan bersifat a priori. Sedangkan empirisisme menekankan bahwa pengetahuan sejati hanya dapat diperoleh melalui pengalaman empiris. 
Oleh karenanya pengetahuan bersifat aposteriori.

Dalam perkembangan selanjutnya pengetahuan empiris-analitis menjadi ilmu alam yang direfleksikan secara filosofis sebagai pengetahuan yang benar mengenai realitas. Pada titik ini ilmu alam dikembangkan sebagai teori murni dengan bantuan rasionalisme dan empirisisme. Mengikuti para filsuf yang menganut ontologi (hakikat) kosmos, para ilmuwan alam pun memahami alam sebagai sebuah kosmos dengan seluruh hukumnya yang teratur, tertib, dan tetap.

Dari rahim filsafat, kemudian lahir positivisme logis yang dirintis oleh Auguste Comté. Bagi positivisme logis, fakta objektif merupakan pengetahuan yang benar. Positivisme logis tidak percaya pada ontologi atau pengetahuan yang melampaui fakta. Budi Hardiman mencatat bahwa meskipun positivisme logis yakin bahwa pengetahuan yang sahih adalah pengetahuan yang berdasarkan fakta dan dengan demikian positivisme logis menyingkirkan ontologi, tetapi positivisme logis tak sanggup melepaskan diri secara total dari ontologi. Hal itu tampak dalam konsep teori yang dianut yakni teori yang bebas dari kepentingan-kepentingan manusiawi (Francisco Budi Hardiman, 1990: 22-26).
Dari positivisme logis inilah lahir sosiologi sebagai ilmu pengetahuan sosial. Positivisme dalam ilmu sosial mengandung tiga pengandaian yang saling bertautan. Pertama, prosedur metodologis ilmu alam dapat diterapkan secara langsung pada ilmu sosial. Artinya, subjektivitas seperti kepentingan dan kehendak manusia sama sekali tidak berpengaruh terhadap perilaku manusia yang menjadi objek yang diamati. Dengan demikian perilaku manusia sebagai objek ilmu pengetahuan setara dengan dunia alamiah. Kedua, hasil penelitian dirumuskan ke dalam 'hukum' sama layaknya dalam ilmu alam. Ketiga, ilmu sosial tidak bisa tidak bersifat teknis yang murni istrumental.

Positivisme logis mendapat perlawanan dari Mazhab Frankfürt yang dikenal dengan sebutan Teori Kritis. Para eksponen Teori Kritis generasi pertama antara lain T.W. Adorno dan Horkheimer berpendapat bahwa positivisme logis merupakan saintisme. Dalam keterangannya, Budi Hardiman memaparkan bahwa Teori Kritis berdiri di tengah ketegangan dialektis antara ilmu pengetahuan khususnya sosiologi dan filsafat. Teori Kritis tidak berhenti pada fakta objektif sebagaimana diagungagungkan oleh positivisme logis. Realitas sosial bagi Teori Kritis merupakan fakta sosiologis yang di dalamnya terdapat 
aspek-aspek transendental yang melampaui data empiris. Dengan demikian Teori Kritis dapat melakukan dua macam kritik yaitu kritik transendental dan kritik immanen. Kritik transendental berupaya menemukan syarat-syarat yang memungkinkan pengetahuan dalam diri subjek. Kritik immanen merupakan upaya menemukan kondisi-kondisi sosio-historis dalam konteks tertentu yang berpengaruh terhadap pengetahuan manusia. Dalam bingkai dua kritik itu, Teori Kritis merupakan Kritik Ideologi (Francisco Budi Hardiman, 1990: 22-26).

Bagi Mazhab Frankfürt, abad Pencerahan telah membuat manusia menghadapi alam dengan kalkulasi. Abad Pencerahan melahirkan konsep rasionalitas yang positivistik. Rasionalitas pencerahan yakni rasionalitas tujuan (rasio intrumental). Pencerahan membuat rasio kehilangan tujuan pada dirinya sendiri. Di tangan positivisme logis, rasio menjadi intrumental, tukang atau alat untuk kalkulasi, verifikasi, dan pelayan klasifikasi meskipun Adorno dan Horkheimer pesimis terhadap rasio itu (Francisco Budi Hardiman, 1990: 64).

Bagi Mazhab Frankfürt, rasionalitas sebagaimana diperjuangkan pencerahan itu tidak memperoleh kemajuan apapun dan menampakkan kembali mitos yang sebelumnya disingkirkan. Rasio abad
Pencerahan justru menciptakan kembali mitos dengan berorientasi pada hal di luar dirinya yakni ekonomi dan politik. Rasio lalu tunduk terhadap ekonomi dan politik. Pola kerja rasio abad Pencerahan itu sama dengan/atau merupakan peniruan (mimesis) pola masyarakat tradisional yang tunduk terhadap sesuatu yang metafisik di luar dirinya. Alih-alih netral dan tak memikirkan tujuan pada dirinya sendiri, rasio abad Pencerahan justru merupakan pengulangan atas mitos lama (Francisco Budi Hardiman, 1990: 64-65).

\section{Etika Diskursus}

Dalam bingkai opitimismenya pada projek modernitas yang ingin segera dituntaskannya, Habermas berupaya membangun sebuah masyarakat yang komunikatif (masyarakat kosmopolit). Masyarakat yang demikian adalah tujuan universal masyarakat. Tentunya ia tidak melepaskan diri dari fakta pluralisme dalam masyarakat modern. Untuk itu ia mengajukan sebuah proposal untuk menata kembali norma-norma hidup bersama, yakni etika diskursus. Etika diskursus yang diajukan Habermas juga merupakan upayanya untuk mengatasi imperatif kategoris dalam Etika Kant yang lebih menekankan prosedur individual atau etika yang dilakukan secara individual. Habermas meragukan tesis Kant bahwa 
sebuah norma dapat berlaku secara universal dipastikan oleh suara hati setiap pribadi. Tesis Kant ini sulit diterapkan dalam masyarakat yang pluralistik (K. White Stephen, 1995: 12). Etika diskursus (William Regh, 1994: 161-166) menuntut dua prinsip pokok yang harus diberlakukan agar norma sungguh-sungguh bersifat moral. Pertama, norma harus dapat diterima oleh semua orang atau berlaku umum. Prinsip ini disebut prinsip universalisasi (prinsip U). "Semua pihak yang (mungkin akan) terkena dampak kepatuhan hukum atas norma dapat menerima konsekuensi dan efek sampingnya, yang diharapkan dapat memenuhi kepentingan setiap orang," demikian ketentuan prinsip $\mathrm{U}$ terkait kesahihan sebuah norma. Kedua, kepastian akan universalisasi norma itu ditempuh melalui diskursus (prinsip D). "Normanorma hanya dapat diklaim sebagai sahih kalau mendapat persetujuan dari semua peserta yang kemungkinan terkena dampak dari norma itu dalam sebuah diskursus praktis," demikian ketentuan prinsip D mengenai klaim kesahihan universalisasi norma.

\section{Demokrasi Deliberatif}

Kata deliberasi berasal dari bahasa Latin deliberatio yang kemudian dalam bahasa Inggris menjadi deliberation. Istilah ini memiliki arti konsultasi, menimbangnimbang, atau dalam istilah politik yakni musyawarah. Pemakaian istilah demokrasi memberikan makna tersendiri bagi konsep demokrasi. Istilah demokrasi deliberatif memiliki makna yang tersirat yaitu diskursus praktis, formasi opini dan aspirasi politik, serta kedaulatan rakyat sebagai prosedur.

Teori demokrasi deliberatif tidak memfokuskan pandangannya dengan aturan-aturan tertentu yang mengatur warga, tetapi sebuah prosedur yang menghasilkan aturan-aturan itu. Teori ini membantu untuk bagaimana keputusankeputusan politis diambil dan dalam kondisi bagaimana aturan-aturan tersebut dihasilkan sedemikian rupa sehingga warganegara mematuhi peraturanperaturan tersebut. Dengan kata lain, demokrasi deliberatif meminati kesahihan keputusan-keputusan kolektif itu. Secara tidak langsung, opini-opini publik di sini dapat mengklaim keputusan-keputusan yang membuat warga mematuhinya.

Di dalam demokrasi deliberatif, kedaulatan rakyat dapat mengontrol keputusan-keputusan mayoritas. Kita sebagai rakyat dapat mengritisi keputusankeputusan yang dibuat oleh orang-orang yang memegang mandat. Jika kita berani mengritisi kebijakan-kebijakan yang dikeluarkan oleh pemerintah, maka secara 
tidak langsung kita sudah menjadi masyarakta rasional, bukan lagi masyarakat irasional. Opini publik atau aspirasi memiliki fungsi untuk mengendalikan politik formal atau kebijakan-kebijakan politik. Jika kita berani mengkritik kebijakan-kebijakan yang legal itu, secara tidak langsung kita sudah tunduk terhadap sistem.

\section{AGAMA DI RUANG PUBLIK}

\section{Akar-Akar Religius pada Rasio Sekuler}

Habermas memang mengakui bahwa negara hukum demokratis atau rasio sekuler mempunyai akar religius, tetapi bukan berarti bahwa basis negara hukum demokratis harus kembali bertumpu pada agama. Dalam sebuah diskusi dengan Kardinal Raztinger yang berlangsung di Katholiche Akademie München, Jerman tanggal 19 Januari 2004, Habermas menggali dan menanggapi secara kritis akar-akar religius rasio sekuler dalam bingkai teks berjudul "Prepolitical Foundations of the Constitutional State?" yang kemudian dibukukan dalam Between Naturalism and Religion, 2008 (Jürgen Habermas, 2008: 101-103). Habermas mengemukakan beberapa pokok pemikirannya. Pertama, negara sekuler tidak mendasarkan diri pada berbagai pengandaian kosmologis tertentu sebagaimana diandaikan hukum kodrat. Konsekuensinya adalah negara sekuler tidak memihak kelompok agama tertentu dengan seluruh sistem nilainya dan setiap warganegara mempunyai kesetaraan dalam memainkan perannya dalam negara hukum demokratis. Dengan mengacu pada pertanyaan kritis yang diajukan Bökenförde tentang seberapa jauh warga dapat menyatukan diri dalam negara dengan jaminan kebebasan individu saja tanpa ada ikatan, Habermas mengatakan bahwa proses demokrasilah yang menjadi ikatan yang menyatukan para warganegara. Proses demokrasi menjadi syarat kemungkinan bagi para warganegara untuk memperjuangkan kepentingankepentingannya.

Tentunya demokrasi yang dimaksudkan Habermas adalah demokrasi deliberatif yang mengacu pada rasio prosedural dan digerakkan oleh rasio komunikatif. Rasio komunikatif yang ada dalam diri warganegara menggerakkan mereka untuk menyatukan diri dalam negara secara bebas dan tanpa tekanan, melalui demokrasi deliberatif.

Kedua, meskipun dari perspektif kognitif dan motivasi negara hukum demokratis bisa mencukupi dirinya secara internal tetapi ada faktor eksternal yang merusak jaringan solidaritas para warganegara dan proses demokrasi yakni 
pasar (Jürgen Habermas, 2008: 107-108). Rasio pasar mempunyai cara kerja yang berbeda dengan rasio negara. Pasar mempunyai metode pengelolaan yang berbeda dengan administrasi negara. Rasio pasar menggiring warga ke dalam individu-individu yang menggunakan kebebasan individualnya secara ketat. Bersamaan dengan itu, bidang-bidang yang menjadi wewenang negara hukum demokratis untuk mengaturnya semakin berkurang. Privatisme warganegara kian menguat, proses demokrasi para warganegara kian melemah. Habermas menyebut fenomena itu sebagai penyimpangan modernisasi. Dalam kondisi seperti ini, negara hukum demokratis melegitimasi dirinya dengan perangkat hukum yang dibuat oleh para warganegara.

Gagasan pokok dalam poin kedua tersebut sudah dikemukakan Habermas ketika ia mengulas masalah duniakehidupan (Lebenswelt) dan sistem. Jika dalam uraiannya tentang dunia-kehidupan dan sistem, Habermas mengatakan bahwa sistem yakni pasar dan negara mengkoloni dunia-kehidupan, dewasa ini rasio pasar sebagai sebuah sistem justru mengkoloni dunia-kehidupan dan negara sekaligus. Dalam situasi kolonisasi rasio pasar yang merupakan bentuk penyimpangan dari modernitas, Habermas mengatakan bahwa para warganegara harus mengatasinya dengan memaksimalkan rasio komunikatif melalui mekanisme rasio prosedural dalam demokrasi deliberatif untuk memperoleh kesepakatan bersama. Itulah yang disebut Habermas sebagai tindakan komunikatif.

Ketiga, menjawab keraguan yang diajukan oleh Bökenförde bahwa apakah negara hukum bisa mencukupi dirinya dengan asas-asas normatif dalam dirinya, Habermas mengatakan bahwa dari perspektif kognitif hukum yang telah mengalami positivasi tetap membutuhkan pandangan religius dan metafisik untuk memastikan secara kognitif prinsip-prinsip hukum dalam negara hukum demokratis (Jürgen Habermas, 1984: 104). Sedangkan dari perspektif motivasi, Habermas mengharapkan bahwa para warganegara menggunakan hak-haknya secara aktif dalam proses pembuatan hukum untuk kepentingan komunal sekaligus kepentingan bersama (Jürgen Habermas, 1984: 105).

Pada poin ini Habermas mengakui bahwa negara hukum demokratis tetap membutuhkan agama atau "kekuatan pemandu" (sustaining power) sebagai pemasti kognitif asas-asas normatif dalam negara hukum demokratis (negara sekuler). Keberadaan agama atau "kekuatan pemandu" yang lain di sini bukan berarti negara mengganti asas-asas normatif dari dirinya dengan asas-asas normatif dari 
agama atau "kekuatan pemandu" lain. Sebaliknya, Habermas hendak mengatakan bahwa agama - dengan asas-asas normatif metafisik - sebagai bagian dari duniakehidupan juga mempunyai kesempatan sama untuk berpartisipasi dalam negara hukum demokratis. Partisipasi agama itu sendiri merupakan bentuk konkrit dari perspektif motivasi. Tentunya model partisipasi tetap dalam bingkai demokrasi deliberatif yang mengacu pada rasio prosedural. Partisipasi agama dalam bingkai rasio prosedural itulah sekaligus merupakan pemasti kognitif rasio prosedural. Dengan kata lain, jika agama tidak diberi kesempatan untuk berpartisipasi dalam negara hukum demokratis, maka demokrasi deliberatif kurang (tidak) memiliki rasionalitas. Jika agama didomestifikasikan dan tidak punya kesempatan untuk berdeliberasi di ruang publik, maka rasio prosedural mengalami defisit rasionalitas. Demokrasi deliberatif memiliki kepastian rasional apabila agama dilibatkan dalam debat-debat di ruang publik politis.

Keempat, Habermas memberi catatan kritis tentang masalah hermeneutika teksteks agama seperti tentang kesalahan dan keselamatan. Hal-hal itu ditafsirkan dan dihayati secara hermeneutik selama bertahun-tahun. Selama teks-teks agama itu tidak mengalami distorsi dalam penafsiran dan tidak jatuh dalam dogmatisme dan pemaksaan suara hati, maka rasio sekuler bisa belajar juga dari agama, masyarakat sekuler dan masyarakat religius bisa saling belajar (Jürgen Habermas, 1984: 108-111).

\section{DARI AGAMA MITIS KE AGAMA RASIONAL}

Habermas mengakui bahwa setiap agama pada hakikatnya adalah "pandangan hidup" atau "comprehensive doctrine" (doktrin yang lengkap) (Jürgen Habermas, 1984: 111). Dengan pendasaranpendasaran mitis dan metafisik, agama juga memberikan elan vital kepada para penganutnya (orang beriman) yang hidup di tengah-tengah masyarakat modern. Bahkan etika substansial yang dianut banyak orang pun berakar pada tradisi agama-agama. Masyarakat modern yang pluralistik itu sendiri terdiri atas orangorang beriman dan orang-orang tidak beriman (Nicholas Adam, 2006: 1). Masyarakat modern berada dalam dua area besar yakni dunia-kehidupan dan sistem yang di dalamnya ada pasar dan negara. Ada masyarakat (individu atau kelompok) sebagai menjadi bagian integral dari duniakehidupan, pasar, dan negara secara serentak. Ada masyarakat (individu atau kelompok) menjadi bagian dari negara dan pasar saja. Masyarakat modern hidup 
dalam sebuah ruang publik (public sphere) yang sama. Ruang publik itu sendiri bersifat politis karena dihuni oleh masyarakat modern yang pluralistik dengan segala kepentingannya. Dalam kondisi masyarakat modern dan ruang publik yang demikian, agama menghadapi tantangan yang serius. Habermas dengan tegas mengatakan bahwa ruang publik politis atau negara hukum demokratis tidak bisa menjadi "religius" atau "ditradisikan" berdasarkan doktrin lengkap agama apapun (Nicholas Adam, 2006: 2). Tampak jelas pendirian Habermas bahwa agama dan negara harus dipisahkan. Agama mempunyai domain kerja yang sangat berbeda dengan negara. Meski demikian agama tidak boleh didomestifikasikan karena bertentangan dengan hakikat demokrasi.

Mengacu pada gambaran idealnya tentang keseimbangan antara duniakehidupan, negara, dan pasar, Habermas menantang - agama yang olehnya dikategorikan sebagai bagian dari duniakehidupan - untuk menunjukkan eksistensinya dalam ruang publik politis atau negara hukum demokratis. Hal itu serius bagi agama karena di satu sisi ajaran-ajaran agama bersifat mitis dan metafisik, di sisi lain ruang publik bersifat rasional dan post-metafisik. Habermas secara tegas berargumen bahwa hanya sebuah forum sekulerlah yang dapat secara memadai menjadi pemandu atau penata bagi perbedaan antara ruang metafisik dan ruang post-metafisik.

Forum sekuler yang dimaksud adalah negara hukum demokratis atau ruang publik politis. Negara hukum demokratislah menjadi forum yang di dalamnya semua partisipan berdeliberasi dan berargumentasi sesuai dengan rasio prosedural untuk mencapai kesepakatan bersama yang merupakan tujuan tindakan komunikatif. Dalam proses deliberasi, pengandaian-pengandaian metafisik agama diuji secara rasional atau dengan cara berpikir post-metafisik. Itu artinya, agama harus mentransformasi diri dari agama mitis (religious-metaphysical) ke agama rasional (religious-post-metafisik) (Nicholas Adam, 2006: 125-126). Pengujian dalam proses deliberasi dan dalam koridor etika diskursuslah agama mitis bisa menjadi agama rasional. Jika menjadi agama rasional, maka etika substansial agama-agama bisa memberi warna dalam etika universal. Meski demikian Habermas tetap tidak mengijinkan agama campur-tangan secara langsung dalam negara. Agama bisa masuk ke dalam negara setelah melewati institusional translation proviso. Lewat itu pengandaian-pengandaian metafisik agama diuji oleh rasio post-metafisik dan bahasa 
agama diterjemahkan ke dalam bahasa rasio sekuler. Dalam konteks ini warganegara yang tidak beriman bisa membantu dalam proses translasi bahasa agama. Jika mekanisme itu dicapai maka agama bisa bermanfaat bagi demokrasi, bermanfaat bagi negara hukum (Habermas, 2008:131-132).

Dengan demikian antara warga beragama dan warga sekuler dalam masyarakat post-sekuler (post-positifikasi rasio) dapat saling belajar satu sama lain. Terlebih bagi warganegara beriman didorong untuk mengenakan cara berpikir (episteme) post-metafisik di tengah pluralitas agama. Warganegara beriman juga mesti belajar dari sains dan teknologi yang memiliki klaim-klaim kesahihan ilmu pengetahuan. Warganegara beriman juga harus tunduk dan mengakui rasio sekuler yang menjadi basis legitimasi negara hukum demokratis (Habermas, 2008:138139).

\section{SIMPULAN}

Habermas berbicara tentang agama bukan karena ia sangat berbakat dalam hal agama, melainkan karena agama merupakan salah satu elemen dalam negara hukum demokratis. Dalam bingkai teori tindakan komunikatif, etika diskursus, dan demokrasi deliberatif, Habermas mengingatkan agama bahwa jika agama ingin bermanfaat bagi negara demokrasi, maka agama harus menerjemahkan bahasa agama ke dalam bahasa sekuler, dan diuji dengan rasio sekuler. Jelas sekali bahwa Habermas menantang sekaligus memberi ruang bagi agama untuk berperan dalam ruang publik politis.

\section{DAFTAR PUSTAKA}

Budi Hardiman. (2009). .Demokrasi Deliberatif-Menimbang Negara Hukum dan Ruang Publik dalam Teori Diskursus Jürgen Habermas. Yogyakarta: Kanisius. (2009). Kritik Ideologi. Yogyakarta: Penerbit Kanisius. . (1990). Kritik Ideologi-

Pertautan Pengetahuan dan Kepentingan. Yogyakarta: Kanisius. .(1993).Menuju Masyarakat Komunikatif. Yogyakarta: Kanisius. (2010). Ruang Publik. Jogjakarta: Penerbit Kansius.

Adam, Nicholas. (2006). Habermas and Theology. Cambrigde: Cambridge University Press.

Bertens. (2002). Filsafat Barat Kontemporer Inggris Jerman. Jakarta: Gramedia.

Paul Budi Kleden, dan Adrianus Sunarko (ed). (2010). Dialektika Sekulerisasi, Diskusi Habermas-Ratzinger dan Tanggapan. Maumere-Yogyakarta: Ledalero-Lamalera.

Franz Magnis Suseno. (2005). Pijar-Pijar Filsafat. Yogyakarta: Penerbit Kanisius. 
Habermas, Jürgen. (2008). Between Naturalism and Religion. Polity: Cambridge.

(1984). The Theory of Communicative Action. vol. 1. Boston: Beacon Press.

Ibrahim Ali Fauzi. (2003). Jürgen Habermas Seri Tokoh Filsafat. Jakarta: Teraju.

Kieser, Bernard. (2004). "Agama Bubar jika Tidak Bercampur Nalar: Being religiosus a la Habermas" dalam Majalah BASIS, nomor 11-12 tahun ke-53 November-Desember.

Listiyono (dkk). (2007). Epistemologi Kiri. Jogjakarta: AR-Ruzzmedia.

Regh, William. (1994). Insight and Solidarity: A Study in the Discourse Ethics of Jurgen Habermas. California: University of California Press.

Stephen, K. White (ed). (1995). The Cambridge Companion to Habermas. New York: Cambridge University Press. 
Humanika, Vol. 16, Nomor 1, September 2016 